\title{
Kinetic modelling of in situ treatment of petroleum hydrocarbon contaminated soil using bone char and NPK fertilizers
}

\author{
Obumneme O. Okwonna *iD and Ipeghan J. Otaraku
}

\begin{abstract}
This study investigates the effectiveness of bone char (organic) and inorganic nitrogen, phosphorous, and potassium (NPK) fertilizers as stimulants in the degradability of petroleum hydrocarbon contaminants on soil. The physicochemical properties of the hydrocarbon sludge were used to assess the effectiveness of this process over an 8-week period using $0.5-3.5 \mathrm{~kg}$ mass of each fertilizer at different experiments. A first order kinetic model was used to estimate the rate of degradation of the total hydrocarbon content (THC) and total organic carbon (TOC) contaminants and the half-life of the remediation process. The microbial population within the period was also determined. The $p$-value $(p<0.05)$ indicated that these fertilizers were effective in degrading these contaminants on the soil, because of the significant difference between the treated and the control soil samples. A direct relationship was observed between with the mass and performance of the fertilizers. With $3.5 \mathrm{~kg}$ mass of the fertilizers, rate constants of 0.018 and $0.019 \mathrm{~d}^{-1}$ were obtained for the removal of the THC and TOC contaminants, respectively, using the bone char fertilizer, whereas NPK fertilizer gave rates of 0.03 and $0.023 \mathrm{~d}^{-1}$ respectively. The performance of the NPK fertilizer is attributable to its nitrogen and phosphorous content. The model adequately described the process and showed the effectiveness of both fertilizers in the remediation process.
\end{abstract}

Keywords: Kinetic model, Bioremediation, Bone char, NPK, Hydrocarbon, Microbial growth

\section{Introduction}

Crude oil exploration and exploitation has given rise to the problem of environmental pollution in many parts of the world. The large-scale production and oil exploration activities in the Niger Delta region of Nigeria, renowned for its huge deposit of crude oil and natural gas reserve, has given rise to oil spillage which has impacted negatively on the environment leading to air, water, and land pollution. The effects on terrestrial and aquatic lives are equally huge and devastating, and these consequences include surface layer poisoning, distortion of macro and micro ecology, as well as other environmental degradation and health impacts. The land desolation,

\footnotetext{
* Correspondence: obumneme.okwonna@uniport.edu.ng

Department of Chemical Engineering, University of Port Harcourt, Port Harcourt 500004, Nigeria
}

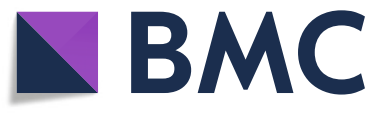

( The Author(s). 2022 Open Access This article is licensed under a Creative Commons Attribution 4.0 International License, which permits use, sharing, adaptation, distribution and reproduction in any medium or format, as long as you give

appropriate credit to the original author(s) and the source, provide a link to the Creative Commons licence, and indicate if changes were made. The images or other third party material in this article are included in the article's Creative Commons licence, unless indicated otherwise in a credit line to the material. If material is not included in the article's Creative Commons licence and your intended use is not permitted by statutory regulation or exceeds the permitted use, you will need to obtain permission directly from the copyright holder. To view a copy of this licence, visit http://creativecommons.org/licenses/by/4.0/. spills lead to reduced agricultural production [1].

To this end, the need for remediation of these soils has become vital. Bioremediation has been shown to be an efficient and viable approach in the management of oil spilled soils. This technique involves the use of microorganisms such as bacteria, yeast, and fungi to degrade toxic and nontoxic substances. Hence, it involves the breakdown of these substances using living organisms $[2,3]$. Various techniques of this approach exist and these include: bio-stimulation, bioaugmentation, bioventing, land farming, phytoremediation, intrinsic bioremediation and controlled natural attenuation, and they could be applied in-situ or ex-situ depending on other factors of consideration [4-8].

This study which considered the bio-stimulation approach involved the enhancement of the hydrocarbon 
degradation process through microbial activities which were stimulated through the addition of nutrients. Bundy et al. [3] and Chorom et al. [9] reported that water, temperature, $\mathrm{pH}$, oxygen content of the soil as well as availability of the contaminants to microorganisms could affect the degradation rate. The most widely reported application of this technique involves the use of nitrogen, phosphorous, and potassium (NPK) fertilizers. Increase in soil $\mathrm{pH}$, mineral leaching, and other environmental effects are among the adverse effects reported with the use of inorganic fertilizers, in addition to the huge cost consideration which remains a significant factor of consideration with these materials. On the other hand, organic fertilizers have been reported to fare better in these areas [10]. This study investigates the effectiveness of bone char (organic) and NPK (inorganic) fertilizers as stimulants in the remediation of an oil contaminated site with a view to determining the kinetics of the process.

\section{Materials and methods}

\subsection{Study area}

An experimental site located within the University of Port Harcourt $\left(4.9069^{\circ} \mathrm{N}, 6.9170^{\circ}\right.$ E), Rivers StateNigeria was used for this study after due authorization by the University research and ethics committee. The area is a tropical rainforest region, which has an average daily minimum temperature of $23^{\circ} \mathrm{C}$ and a mean temperature of $31.5^{\circ} \mathrm{C}$. It has about seven (7) months of rainfall annually (April to October), an average annual rainfall of $2400 \mathrm{~mL}$, and a mean relative humidity of $85 \%$ per month.

\subsection{Sample preparation 2.2.1 NPK fertilizer}

$30 \mathrm{~kg}$ of NPK fertilizer was purchased from a commercial retail outlet in Port Harcourt metropolis, Rivers State, Nigeria.

\subsubsection{Bone char fertilizer}

Bone char sourced from an abattoir within the study area was subjected to pyrolysis treatment at the Chemical Engineering laboratory, University of Port Harcourt, to obtain an organic fertilizer.

\subsubsection{Crude oil sample}

The crude oil sample used for this experiment was sourced from an oil spill site at Abua/Odual local government area, Rivers state-Nigeria using a plastic container. $200 \mathrm{~L}$ of the crude sample was collected from recovery tanks installed by the clean-up contractor. The sample was collected under the supervision and assessment of department of petroleum resources to ensure conformity and compliance with product and environment standards. Other chemicals used in this experiment were purchased from a retail outlet, Austino laboratory services ltd. Choba, Port Harcourt (Nigeria) and were of analytical grade.

\subsection{Soil preparation and in-situ bioremediation procedure}

The land portion, with no known history of crude oil contamination, was segmented into 7 cells of similar dimension demarcated from each other with a $10 \mathrm{~cm}$ wooden structure. Each cell, having a dimension of $1.5 \times 1.5 \mathrm{~m}$ and a depth of $30 \mathrm{~cm}$ (contaminated soil depth), was polluted with $20 \mathrm{~L}$ of the crude oil sample to form a sludge which was allowed to stand for 2 wk. under continuous monitoring. At the end of this period, the vegetations on the study site were observed to have died. Thereafter, different concentrations of the bone char and NPK fertilizers were administered on these cells (Table 1), and the soil tilled to expose its surface area for treatment and to enhance oxygen availability to bacteria and fungi for effective chemical reactions. Tilling of the soil was done once in every 3 days whereas a daily irrigation of the site helped ensure that the optimal soil moisture condition of the site was maintained. Moreover, the experiment was conducted in an uncontrolled environment during the dry season. The effect of bioremediation on the contaminated soil was observed for a period of $8 \mathrm{wk}$. Previous studies by Daka et al. [11] and Ayotamuno et al. [12] employed a similar approach under different experimental conditions.

The analytical soil samples were collected at depths of 6,18 , and $27 \mathrm{~cm}$ from the cells at the experimental site using a spade. The soil samples were, thereafter, mixed into composite samples, labeled and sealed in small polyethylene bags for analysis.

\subsection{Characterization of soil sample}

Physicochemical properties such as $\mathrm{pH}$, total hydrocarbon content (THC), organic carbon, extractable phosphorous and total nitrogen content were used as indices to evaluate the contamination levels of the soil. Samples collected from contaminated site were air dried and

\begin{tabular}{|c|c|c|c|c|}
\hline \multirow{2}{*}{$\begin{array}{l}\text { Serial } \\
\text { number }\end{array}$} & \multirow{2}{*}{$\begin{array}{l}\text { Site } \\
\text { Code }\end{array}$} & \multicolumn{3}{|l|}{ Treatment } \\
\hline & & Crude oil sludge (L) & NPK (kg) & Bone char $(\mathrm{kg})$ \\
\hline 1 & $C$ & 20 & - & - \\
\hline 2 & $x_{1}$ & 20 & 0.5 & - \\
\hline 3 & $x_{2}$ & 20 & - & 0.5 \\
\hline 4 & $Y_{1}$ & 20 & 2 & - \\
\hline 5 & $Y_{2}$ & 20 & - & 2 \\
\hline 6 & $Z_{1}$ & 20 & 3.5 & - \\
\hline 7 & $\mathrm{Z}_{2}$ & 20 & - & 3.5 \\
\hline
\end{tabular}

NB: $C$ is the control experiment 
homogenized by passing them through a $2 \mathrm{~mm}$ mesh sieve. The physiochemical properties were determined as follows:

\subsubsection{THC}

$10 \mathrm{~g}$ of the representative soil sample was shaken vigorously with $10 \mathrm{~mL}$ of $\mathrm{n}$-hexane for $10 \mathrm{~min}$. The extract was analyzed with $420 \mathrm{~nm}$ Bausch \& Lamb spectronic-70 spectrophotometer (Bamko-surplus, Texas, United States). The concentration of the extract was obtained from the spectrophotometer and compared with a standard curve of another substance with known concentration. The THC was evaluated with reference to the American Society for Testing and Materials D 9071 procedure and multiplied by the appropriate dilution factor in line with the study of Ikiogha et al. [13].

\subsubsection{Total nitrogen (TN)}

$2 \mathrm{~g}$ of the soil sample was air died, weighed and added into a $150 \mathrm{~mL}$ beaker. $10 \mathrm{~mL}$ each of the following were added alongside: selenium, copper sulphate, sodium sulphate, and sulphuric acid $\left(\mathrm{H}_{2} \mathrm{SO}_{4}\right)$. These reagents were of analytical grade. The mixture was agitated by gentle swirling and digested in a Foss Tecator digester (Kjedahl $^{\mathrm{Tm}}$ Model 2300, Pittsburgh, USA) for 15 min until an ash coloured solution was formed. The setup was heated for $1 \mathrm{~h}$ and cooled for about same time. The digest was emptied into a $250 \mathrm{~mL}$ capacity beaker and made up with distilled water. An auto-analyzer was used to determine the ammonium nitrogen of the aliquots. The percentage nitrogen content was thereafter evaluated with due consideration of the dilution factors.

\subsection{3 $\mathrm{pH}$}

This was done using a corning $\mathrm{pH}$ meter model 7 (Corning Scientific, NY, USA) by dipping the electrode into a 1:25 sample and water suspension which had been stirred and allowed to equilibrate for about $1 \mathrm{~h}$.

\subsubsection{Phosphorous content}

The phosphorus content was determined using the Bray and Kurtz method [14]. $2.85 \mathrm{~g}$ of sample was weighed into a clean and dry sample bottle. $20 \mathrm{~mL}$ of Bray No. 1 extractant was added $\left(0.025 \mathrm{~N} \mathrm{HCl}+0.03 \mathrm{~N} \mathrm{NH}_{4} \mathrm{~F}\right)$ and shaken for $60 \mathrm{~s}$. Thereafter, $10 \mathrm{~mL}$ filtrate was added into a $50 \mathrm{~mL}$ capacity volumetric flask using a pipette. The mixture was diluted (made up) with about $20 \mathrm{~mL}$ of distilled water, after which $4 \mathrm{~mL}$ ascorbic acid solution was added. This setup was allowed to rest for $30 \mathrm{~min}$, during which a change in colour was observed, before being analyzed with a spectronic-20 spectrophotometer operating at $660 \mathrm{~nm}$ wavelength. This analysis was carried out in accordance with the manufacturer's specification.

\subsubsection{Total organic carbon (TOC)}

This was evaluated using the wet combustion method by measuring $1 \mathrm{~g}$ of the finely ground soil sample into 3 different $500 \mathrm{~mL}$ beakers with $10 \mathrm{~mL}$ of potassium dichromate solution added alongside amidst continuous stirring using a magnetic stirrer. $20 \mathrm{~mL} \mathrm{H}_{2} \mathrm{SO}_{4}$ was added to the content of the beakers using a graduated cylinder and, thereafter, the beaker was rotated and allowed to stand for $10 \mathrm{~min}$ while distilled water was equally added for dilution, by making up the solution to the $200 \mathrm{~mL}$ mark of the beaker. $25 \mathrm{~mL}$ of $10.5 \mathrm{~N}$ ferrous ammonium sulphate and $0.4 \mathrm{~N}$ potassium permanganate were also added under strong light.

\subsubsection{Soil texture}

This was evaluated using the Bouyoucous hydrometer [15] in accordance with the method of Day [16].

\subsection{Evaluation of microbial population}

This process was carried out using the methods of Barrow and Feltham [17] and Garrity et al. [18]. Prior to the experimental process, all the media and diluents were first sterilized in an autoclave operating at a temperature condition of $120^{\circ} \mathrm{C}$ for $15 \mathrm{~min}$. The glass wares were dried in a hot air oven for $3 \mathrm{~min}$. The saline solution was prepared by weighing 0.85 sodium chloride solution which was thereafter transferred into the various $9 \mathrm{~mL}$ capacity test tubes used for the experiments for sterilization under a temperature condition of $120^{\circ} \mathrm{C}$ for $15 \mathrm{~min}$. The solution was also used for the serial dilution of the soil samples. Cultivation and enumeration of the soil bacteria was done by adding $1 \mathrm{~g}$ of the air-dried soil sample into $1 \mathrm{~mL}$ of the sterile distilled water amidst vigorous agitation to obtain a homogeneous mixture. $1 \mathrm{~mL}$ of the $10^{-1}$ solution was added into a $9 \mathrm{~mL}$ test tube containing the diluents and serially diluted stepwise to obtain a $10^{-3}$ dilution. A spatula was used to transfer $0.1 \mathrm{~mL}$ aliquot of the solution into the sterilized nutrient agar plates in such a way that most of the surface area was exposed for reaction. The inoculated plates were incubated at a temperature of $37^{\circ} \mathrm{C}$ for $24 \mathrm{~h}$, before the nutrient agar plates were examined for bacterial growth. The total viable heterotrophic bacteria were evaluated based on the number of the Colony Forming Units (CFU) using the colony counting technique to determine the number of cells capable of splitting [19]. The CFU was evaluated using the correlation: $\mathrm{CFU} \mathrm{mL}^{-1}=$ number of colonies $\times$ dilution factor/volume of culture plate.

\subsubsection{Identification and isolation of soil bacteria}

The bacteria culture was isolated by aseptically streaking colonies of different culture seen on the plate to a freshly prepared nutrient agar plate. The setup was incubated at $28{ }^{\circ} \mathrm{C}$ and allowed to stand for $24 \mathrm{~h}$ to allow the 
bacteria grow. Based on the colony morphology and exhibition of zones of inhibition on the primary culture, isolates were selected. Isolate purification was done using dilute nutrient broth and agar media and stocked at $-80^{\circ} \mathrm{C}$. Characterization of these isolates was done using Gram stain (methyl and violet test) to confirm the bacterial growth while the viable count was conducted manually. The isolates were observed under an inverted microscope at $\times 100$ oil immersion following the method of Khan et al. [20] while the CFU was evaluated.

\subsubsection{Isolation and identification of soil fungi}

This was done using dilution plate method on potato dextrose agar. Isolates of soil fungi which were examined macroscopically and microscopically were identified by matching the characteristics of the fungus obtained from observations in accordance with the work of Umboh et al. [21].

\subsection{Kinetics of the process}

A description of the process was evaluated using a firstorder kinetic model in the form of Eq. (1).

$$
\ln (1-F E)=-k_{1} t
$$

where:

$$
F E=\frac{C_{0}-C_{t}}{C_{0}}
$$

$\mathrm{FE}=$ fractional efficiency.

$\mathrm{C}_{\mathrm{o}}=$ initial concentration.

$\mathrm{C}_{\mathrm{t}}=$ concentration at time $\mathrm{t}$.

$\mathrm{t}=$ elapsed time.

\subsection{Degradation}

Degradation of the contaminants was evaluated from the initial and residual concentrations of the THC and TOC, respectively using Eq. (3).

$$
D=\frac{T C_{0}-T C_{i}}{T C_{0}} \times 100
$$

where:

$\mathrm{TC}_{0}=$ initial concentration.

$\mathrm{TC}_{\mathrm{i}}=$ residual concentration .

\subsection{Bio-stimulation efficiency}

The bio-stimulation efficiency was used to estimate all the treatability options provided by the optimization

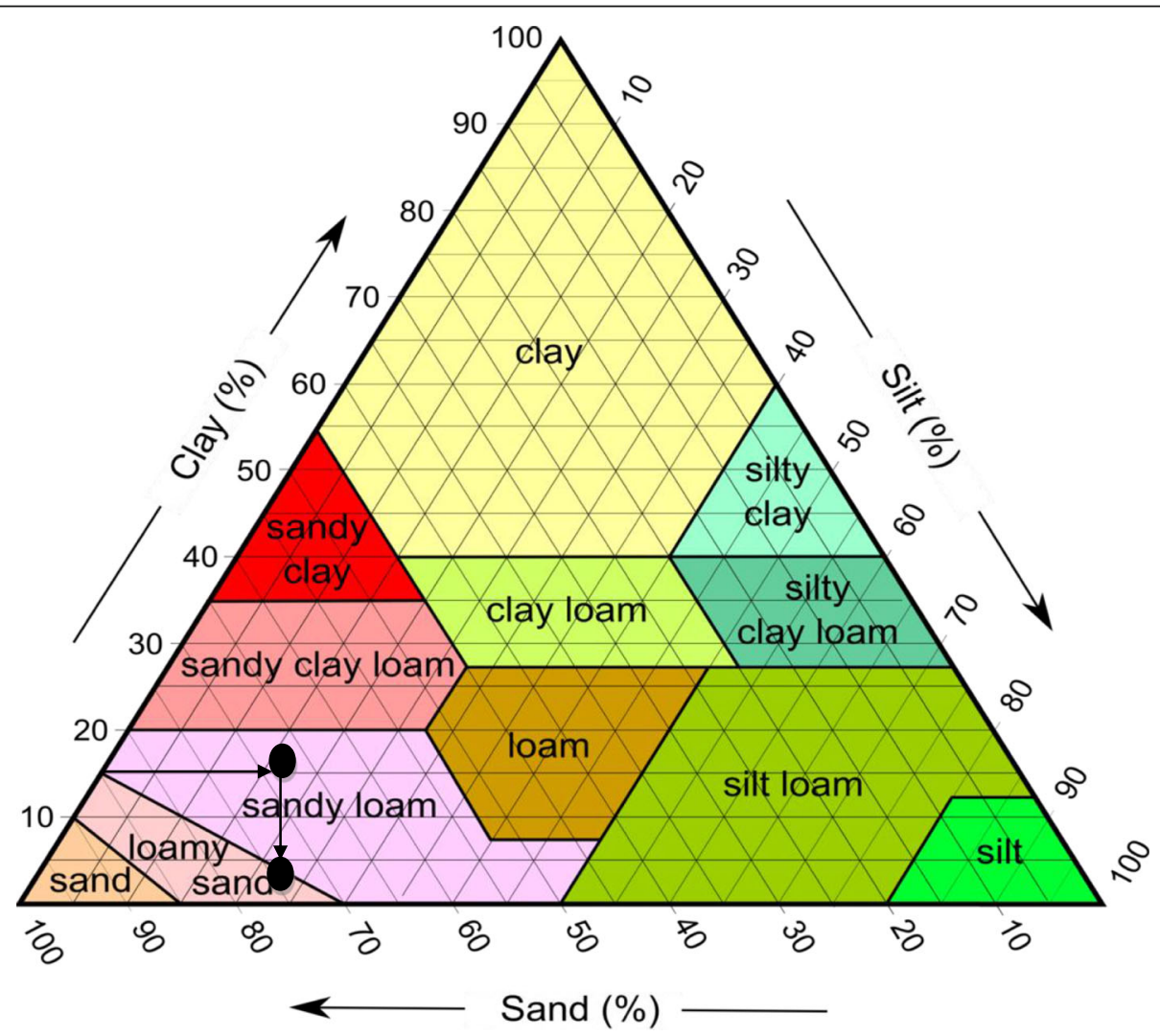

Fig. 1 Soil texture triangle 
rates of the bio-stimulants and was obtained using Eq. (4). This was done to ascertain the effect of the biotic and abiotic factors in the bioremediation process.

$$
B E=\frac{C_{t}-C_{u}}{C_{t}}
$$

where:

$\mathrm{BE}=$ bio-stimulation efficiency.

$\mathrm{Ct}=$ percentage of crude oil removed from the treated soil.

$\mathrm{Cu}=$ percentage of crude oil removed from the untreated soil (control).

\subsection{Statistical analysis}

t-test was used to analyze the obtained THC data to evaluate the bioremediation process on the contaminated soil. The choice of the test instrument was based on the sample size $(n<30)$. The treated soil samples were compared with that of the control site and the following conditional statements were considered:

i. If $p>0.05$ accept null hypothesis $\left(H_{o}\right)$ (no appreciable effect on the process) and reject alternative hypothesis $\left(H_{i}\right)$ (significant effect on the process).

ii. If $p<0.05$ reject null hypothesis $\left(H_{o}\right)$ (no appreciable effect on the process) and we accept alternative hypothesis $\left(H_{i}\right)$ (significant effect on the process).

The Pearson correlation coefficient and t-stat values were also obtained. Microsoft excel and SPSS version 17 were used for this process.

\section{Results and discussion}

\subsection{Soil properties}

The particle size analysis of the soil texture within the depth of interest $(30 \mathrm{~cm})$ prior to treatment showed it to comprise of the following: soil- $75 \%$, clay- $15 \%$ and silt$10 \%$. The soil texture, which is a classification of the soil based on its physical characteristics, was used to assess the soil sample to ascertain the air and water retention capability, rate of water movement in and out of the soil, as well as the ease of working with the soil sample. The texture triangle (Fig. 1) indicates the soil texture to comprise of both sand and loamy sand and is consistent with the work of Odokuma and Dickson [22] for the top soil of tropical rainforest.

Table 2 Physicochemical and microbial properties of soil samples

\begin{tabular}{|c|c|c|c|}
\hline \multirow[t]{2}{*}{ Description } & \multirow[t]{2}{*}{ Property } & \multicolumn{2}{|l|}{ Soil sample } \\
\hline & & Uncontaminated & Contaminated \\
\hline \multirow[t]{17}{*}{ Physicochemical properties } & Soil porosity (\%) & 85 & 52 \\
\hline & THC $\left(\mathrm{mg} \mathrm{kg}^{-1}\right)$ & 137 & 19,850 \\
\hline & TN (\%) & 0.85 & 0.27 \\
\hline & $\mathrm{pH}$ & 5.86 & 6.74 \\
\hline & Phosphorous (mg kg ${ }^{-1}$ ) & 18.2 & 6.4 \\
\hline & TOC (\%) & 3.28 & 8.52 \\
\hline & Nitrate $\left(\mathrm{mg} \mathrm{kg}^{-1}\right)$ & 0.85 & 0.27 \\
\hline & Phosphate $\left(\mathrm{mg} \mathrm{kg}^{-1}\right)$ & 55.9 & 84.3 \\
\hline & Sodium $\left(\mathrm{mg} \mathrm{kg}^{-1}\right)$ & 10.3 & 4.2 \\
\hline & Potassium $\left(\mathrm{mg} \mathrm{kg}^{-1}\right)$ & 163.7 & 42.8 \\
\hline & Calcium (mg kg ${ }^{-1}$ ) & 1306 & 154 \\
\hline & Sulphate $\left(\mathrm{mg} \mathrm{kg}^{-1}\right)$ & 5.9 & 13.9 \\
\hline & Sodium adsorption ratio & 2.1 & 11.5 \\
\hline & Moisture content (\%) & 8.46 & 6.24 \\
\hline & Oil and grease $\left(\mathrm{mg} \mathrm{L}^{-1}\right)$ & 306 & 14,721 \\
\hline & CEC (meq $100 \mathrm{~g}^{-1}$ ) & 14 & 74 \\
\hline & Electrical conductivity $\left(\mu \mathrm{S} \mathrm{cm}^{-1}\right)$ & 30 & 79 \\
\hline \multirow[t]{3}{*}{ Microbial properties } & $\mathrm{TBC}\left(\mathrm{CFU} \mathrm{mL}^{-1}\right)$ & $3.5 \times 10^{6}$ & $1.3 \times 10^{2}$ \\
\hline & $\mathrm{HUB}\left(\mathrm{CFU} \mathrm{mL}^{-1}\right)$ & $2.2 \times 10^{2}$ & $1.6 \times 10^{2}$ \\
\hline & HUF (SFU mL $\left.{ }^{-1}\right)$ & $1.1 \times 10^{2}$ & $1.0 \times 10^{2}$ \\
\hline
\end{tabular}


Table 3 Physicochemical properties of bone char and NPK fertilizers

\begin{tabular}{llll}
\hline Serial number & Property & Amount \\
\cline { 3 - 4 } & & Bone char & NPK \\
\hline 1 & $\mathrm{pH}$ & 7.18 & 7.01 \\
2 & Moisture content (\%) & 1.86 & 1.0 \\
3 & Density $\left(\mathrm{g} \mathrm{mL}^{-1}\right)$ & 3.06 & 1.26 \\
4 & Porosity (\%) & 5.8 & 15 \\
5 & Calcium ion (mg kg & - $)$ \\
6 & Total Nitrogen (\%) & 3740 & 0 \\
7 & Potassium (\%) & 98.2 & 15 \\
8 & Phosphorous (\%) & 0 & 15 \\
\hline
\end{tabular}

The physicochemical properties and microbial properties of the sandy loam soil (Table 2) were adversely affected by the contamination of the petroleum hydrocarbon. Both the trace metal contents and the microbial population of the soil were greatly depleted. The
$\mathrm{pH}$ conditions in this study were optimum and favourable for microbial growth and higher than the minimum growth $\mathrm{pH}$ from previous findings [23]. Slight changes in the $\mathrm{pH}$ could alter the ionization of aminoacid functional groups and interfere with the hydrogen bonding leading to their denaturation thereby rendering them ineffective for use in the biodegradation of the hydrocarbon [24]. This study corroborates previous findings on the effect of petroleum hydrocarbon contamination on soil moisture [25]. Increase in the electrical conductivity and cation exchange capacity (CEC) indicates the dissociation of ion charges into the soil due to crude oil contamination. These ions are attracted to the water molecules in the soil which carry polar charges. The ionic solutions become electrolytes capable of conducting electricity.

\subsection{Fertilizer properties}

The physiochemical properties of the bone char and NPK fertilizers (Table 3) are presented. The constituents of these fertilizers and their physical properties are

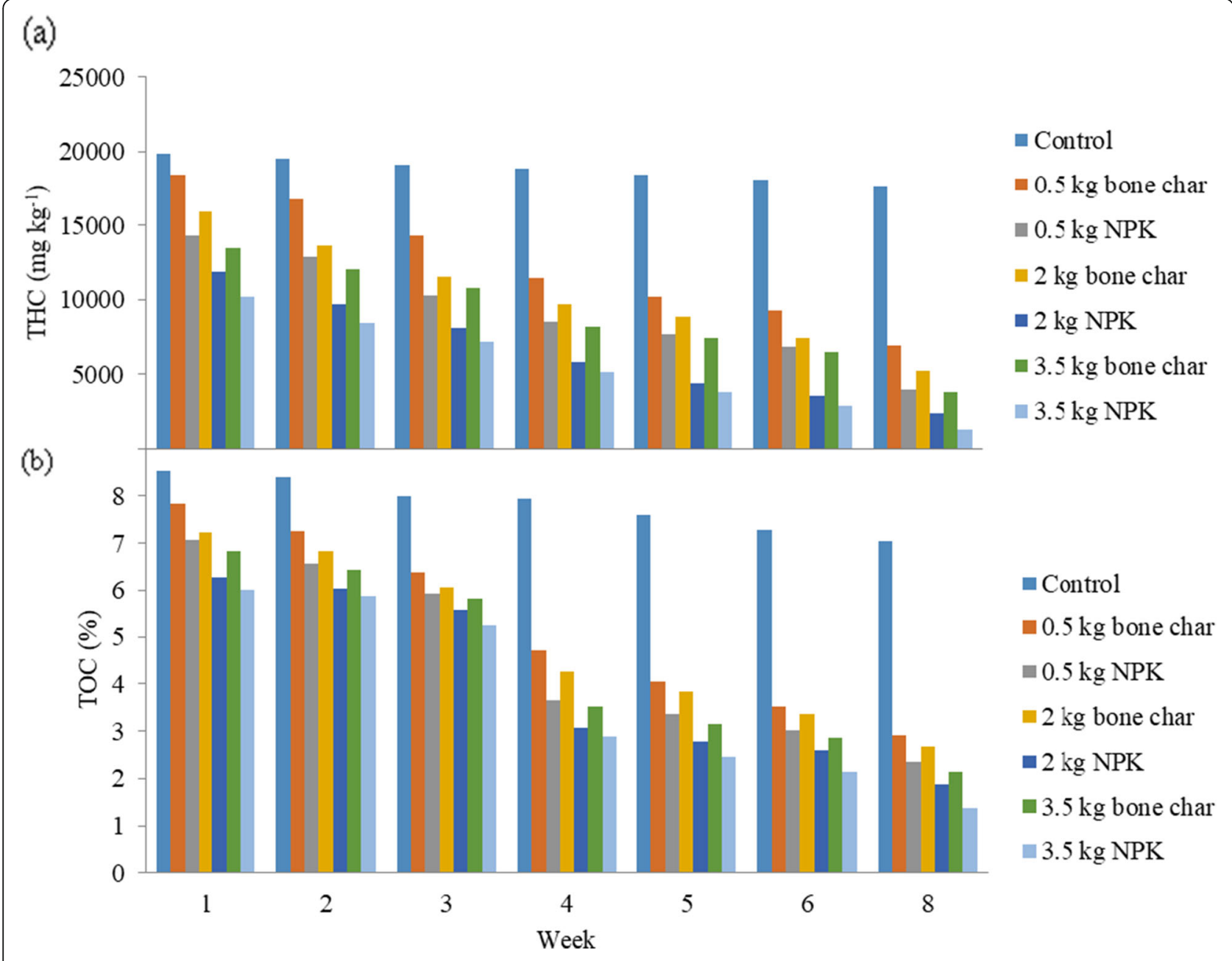

Fig. 2 Effect of bioremediation treatment on (a) THC (b) TOC 
critical to their performance in the degradation of the hydrocarbon contaminant.

The effect of the structural-mechanical properties of fertilizer granules has been reported [26] and these are fundamental in the exposure of the reactant surface area necessary for these reactions to occur as well as for the interaction of the microbes with the substrate. Various authors have shown the effect of these fertilizers on growth characteristics and soil nutrients [27-30] and bioremediation [31-35]. This study corroborates these findings.

\subsection{Effect of in-situ treatment of the contaminated soil}

The effect of both grades of fertilizers (organic and inorganic) on the experimental site was evaluated through an analysis of the physicochemical properties of the soil samples (Table 2) and the THC (Fig. 2a) of the soil.

Both grades of fertilizer drastically reduced the THC of the contaminated soil over time. This indicates that bioremediation was effective in reducing the THC from the contaminated soil. There is a link between the mass of fertilizer and performance in the bioremediation process for both grades of fertilizers. $3.5 \mathrm{~kg}$ mass of both fertilizers had the highest reduction of the THC and TOC contaminants; efficiency for all treated samples on the THC was above $60 \%$ (Fig. 3a). Comparatively, the NPK grade gave a better performance than the bone char. The effectiveness of the bone char grade of fertilizer could be linked with its ion content leading to the degradation of the hydrocarbon contaminant [36]. A similar pattern was observed for the TOC (Fig. 2b and 3b) within this period which confirms the bioremediation effects of these grades of fertilizers.

The bacillus and pseudomonas species were predominant on the contaminated soil. Addition of these fertilizers resulted in a significant increment in the heterotrophic bacteria and heterotrophic fungi. Total Bacterial Count (TBC) was used to obtain a quantitative idea of the microorganisms present in the soil. TBC is indicative of the number of CFU of the soil sample and formed the basis to

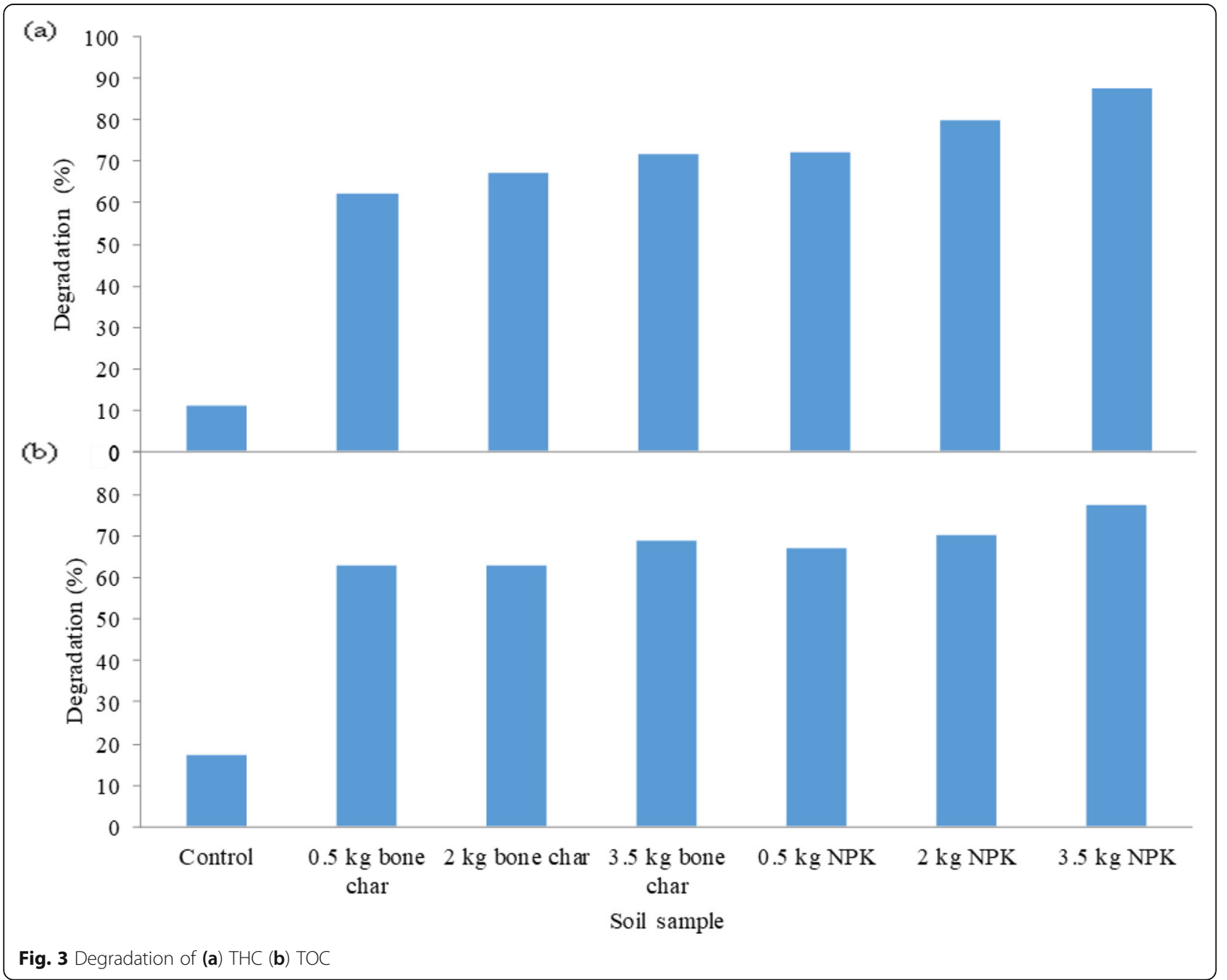


analyze the degradation rate of the crude oil in the polluted soil. Prolonged period of the bioremediation treatment with both grades of fertilizers favoured the production of the microbes (Fig. 4a). The NPK fertilizer grade gave higher bacterial count than the bone char whereas higher mass of both fertilizers favoured the TBC and consequently their performance in the remediation process. Chorom et al. [9] reported that excessive application of fertilizers makes survival conditions of these microbes critical.

Hydrocarbon Utilizing Bacteria (HUB) degrades aliphatic alkanes through various metabolic activities. They utilize the linear hydrocarbon chains in petroleum as their main energy source under aerobic conditions. Additionally, when exposed with other sufficient limiting nutrients like nitrogen and phosphorous, they produce surfactant glycolipids which help reduce water tension and the uptake of hydrocarbon, e.g., Alcanivorax borkumensis. Performance of the both grades of fertilizer in the isolation of the HUB was shown to be time and dose-dependent (Fig. 4b). The higher performance of the NPK fertilizer in the remediation process could be attributed to its higher nitrogen and phosphorous content which makes it possible to isolate more of the desirable microbe population to produce the surfactant glycol lipids that reduce surface tension thereby making it possible to degrade the contaminant hydrocarbon. The biostimulation efficiency (Fig. 5) further corroborates this.

Similarly, hydrocarbon utilizing fungi (HUF) has proven to be very effective in the removal of a wide array of toxins or contaminants from the environment. This is achieved through the degradation of the hydrocarbon

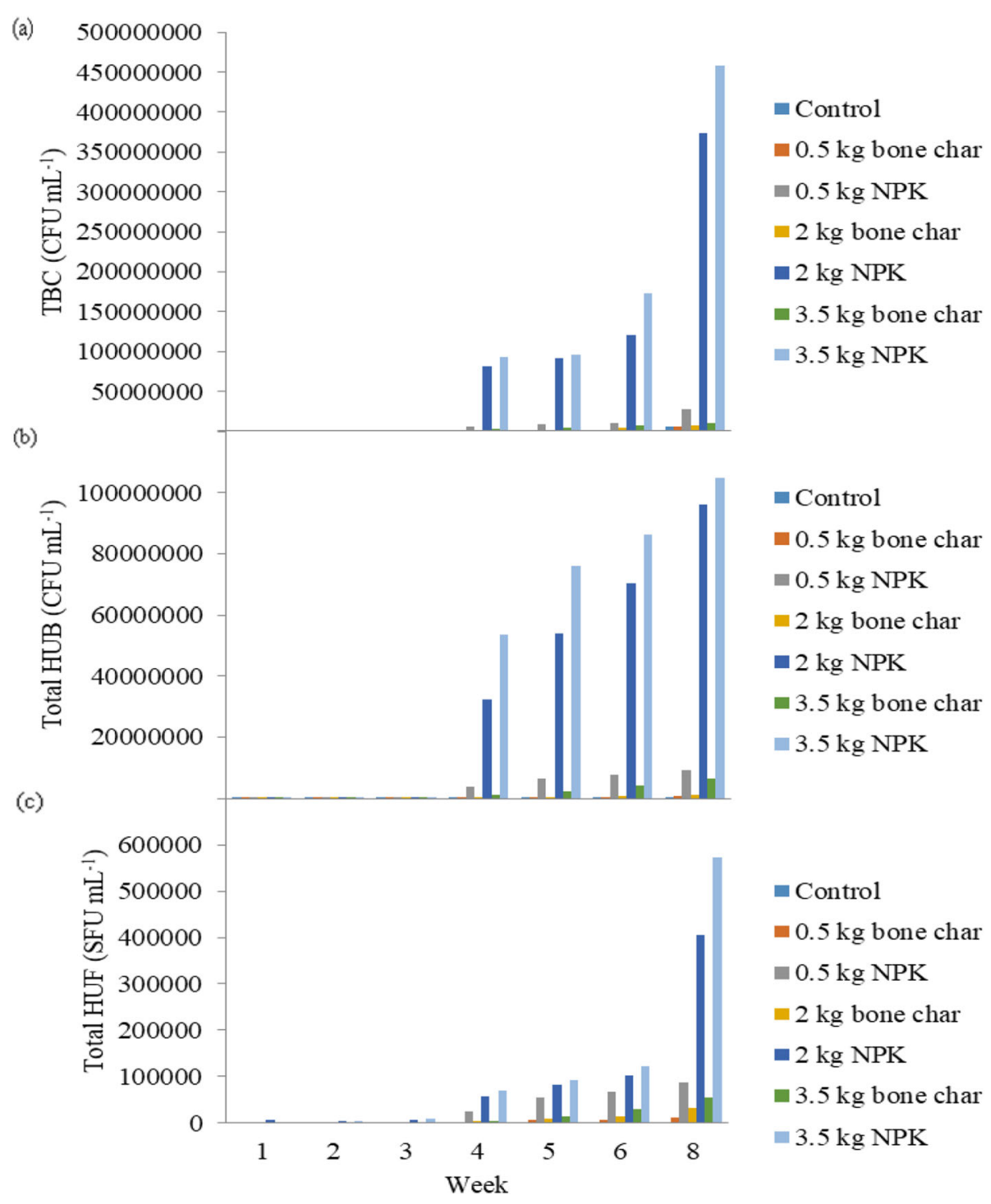

Fig. 4 Effect of treatment on (a) TBC (b) HUB (c) HUF 


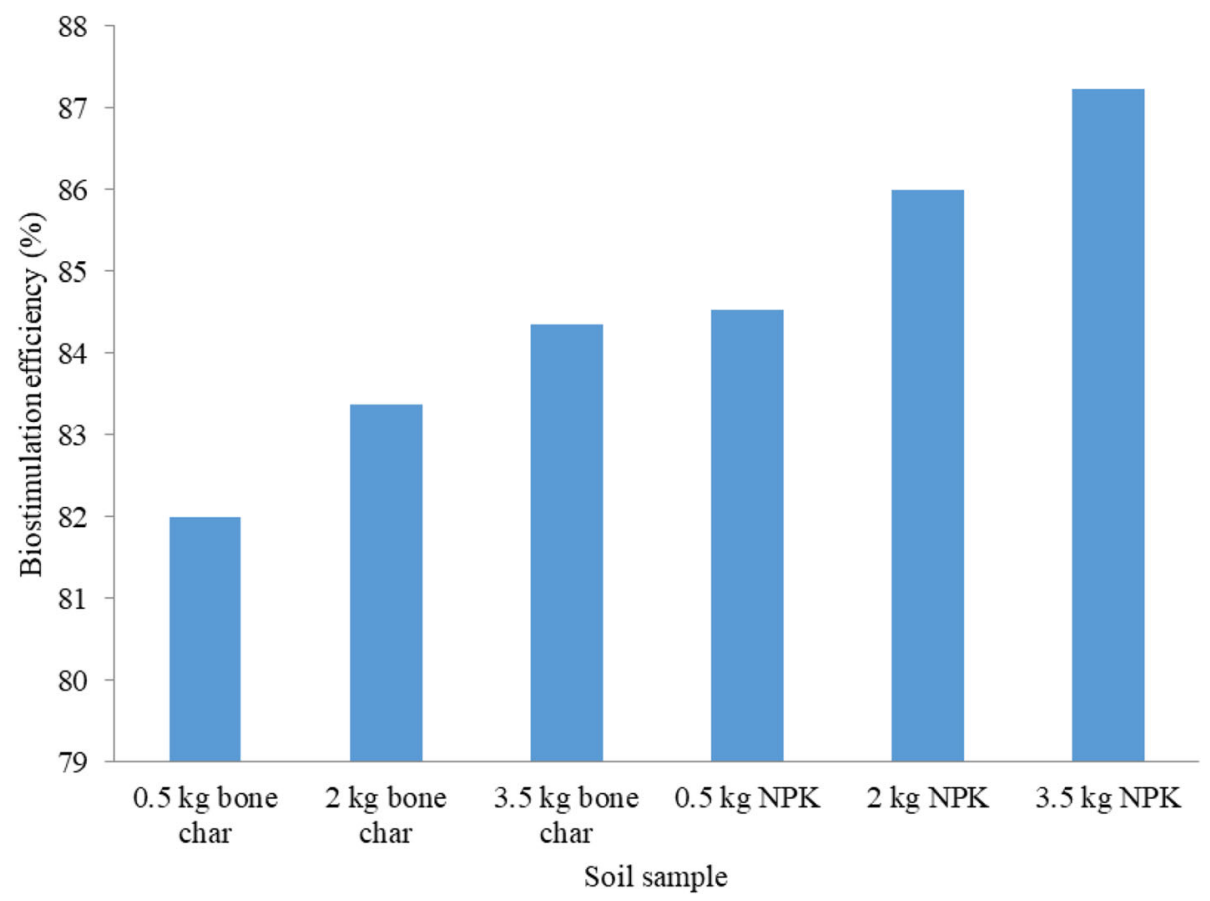

Fig. 5 Biostimulation efficiency

components to non-toxic substances. The growth rate of the HUF (Fig. 4c) followed a similar pattern as that of the HUB, and the NPK fertilizer favoured the production of the HUF as it consistently gave a higher count of the HUF than the bone char within the period of study. Performance of the both grades of fertilizer in the isolation of the HUF has been shown to be time and dosedependent. Kumar et al. [37] and Chikere et al. [38] reported the species of this as being capable of degrading petroleum hydrocarbons in contaminated soils: Penicillium sp., Candida sp., A. Niger, Rhizopus sp., Mucor sp., Talaromyces sp., Saccharomyces sp., Cladosporium sp., Fusarium sp., Rhodotorula sp. and Aspergillus flavus.

The steady increase in the growth rate of these microorganisms with time entails a rapid reproduction of the crude oil degrading mechanisms which were responsible for the attenuation of the soil contaminants and this corroborates the works of Chikere et al. [31].

\subsection{Statistical analysis}

The results of the statistical analysis are shown (Table 4). The $\mathrm{R}^{2}$, $\mathrm{t}$-stat and $p$-values were used to study the effectiveness of the bioremediation treatment in the removal of the THC and TOC contents. The analysis was done in comparison with the control sample based on the pvalue for significance level $(p<0.05)$. Appreciable significant differences were observed for all the samples. Hence we reject the null hypothesis $\left(H_{0}\right)$ and accept the alternative hypothesis $\left(H_{i}\right)$. There was significant effect of the remediation treatment process on the contaminated soil which gave rise to an appreciable reduction of THC and TOC.

\subsection{Kinetics of the process}

The first order kinetic model, which proposes that rate of degradation of substrate is directly proportional to its concentration, was used to model the degradation level of THC and TOC in the contaminated soil. High k value implies high degradation rate (Table 5), while the fractional efficiency was plotted against time for all samples (Fig. 6a-f).

Positive correlations were observed for the degradation of THC and TOC in the soil with respect to time. In both cases, $3.5 \mathrm{~kg}$ NPK treatment had the highest degradation rate constant $\left(0.03\right.$ and $\left.0.023 \mathrm{~d}^{-1}\right)$ and

Table 4 Statistical analysis

\begin{tabular}{|c|c|c|c|c|c|c|}
\hline \multirow[t]{3}{*}{ Soil sample } & \multicolumn{6}{|c|}{ Statistical parameters } \\
\hline & \multicolumn{3}{|l|}{ THC } & \multicolumn{3}{|l|}{ TOC } \\
\hline & $\overline{R^{2}}$ & t-Stat & $\overline{p \text {-value }}$ & $\overline{R^{2}}$ & t-Stat & $\overline{p \text {-value }}$ \\
\hline ne char & 0.9865 & 4.92811 & 0.00264 & 0.96638 & 4.87701 & 0.00277 \\
\hline $5 \mathrm{~kg}$ & 0.9878 & 9.04522 & 0.0001 & 0.93465 & 6.14734 & 0.00085 \\
\hline $2 \mathrm{~kg}$ bone & 0.9919 & 7.70261 & 0.00025 & 0.95774 & 6.07293 & 0.00091 \\
\hline $\mathrm{kg} / \mathrm{ir}$ & 0.9826 & 12.0418 & $2 \mathrm{E}-05$ & 0.91986 & 7.3 & 0.000 \\
\hline $3.5 \mathrm{~kg}$ bone char & 0.9885 & 10.0233 & 5.7E-05 & 0.93606 & 6.47146 & 0.00065 \\
\hline $3.5 \mathrm{~kg} \mathrm{NPK}$ & 0.9929 & 14.476 & $6.8 \mathrm{E}-06$ & 0.93571 & 7.56739 & 0.00028 \\
\hline
\end{tabular}


Table 5 Summary of the kinetic model parameters for THC and TOC reduction

\begin{tabular}{|c|c|c|c|c|c|c|}
\hline \multirow[t]{3}{*}{ Treatment condition } & \multicolumn{6}{|c|}{ Model parameters } \\
\hline & \multicolumn{3}{|l|}{ THC } & \multicolumn{3}{|l|}{ TOC } \\
\hline & $\overline{R^{2}}$ & $k\left(d^{-1}\right)$ & Half life (d) & $\overline{R^{2}}$ & $k\left(d^{-1}\right)$ & Half life (d) \\
\hline Control & 0.959 & 0.002 & 347 & 0.918 & 0.003 & 231 \\
\hline $0.5 \mathrm{~kg}$ bone char & 0.938 & 0.016 & 43 & 0.912 & 0.017 & 41 \\
\hline $2 \mathrm{~kg}$ bone char & 0.951 & 0.018 & 38 & 0.898 & 0.017 & 41 \\
\hline $3.5 \mathrm{~kg}$ bone char & 0.891 & 0.018 & 38 & 0.874 & 0.019 & 36 \\
\hline $0.5 \mathrm{~kg} \mathrm{NPK}$ & 0.909 & 0.019 & 36 & 0.882 & 0.019 & 36 \\
\hline $2 \mathrm{~kg} \mathrm{NPK}$ & 0.94 & 0.027 & 26 & 0.848 & 0.02 & 35 \\
\hline $3.5 \mathrm{~kg} \mathrm{NPK}$ & 0.882 & 0.03 & 23 & 0.853 & 0.023 & 30 \\
\hline
\end{tabular}

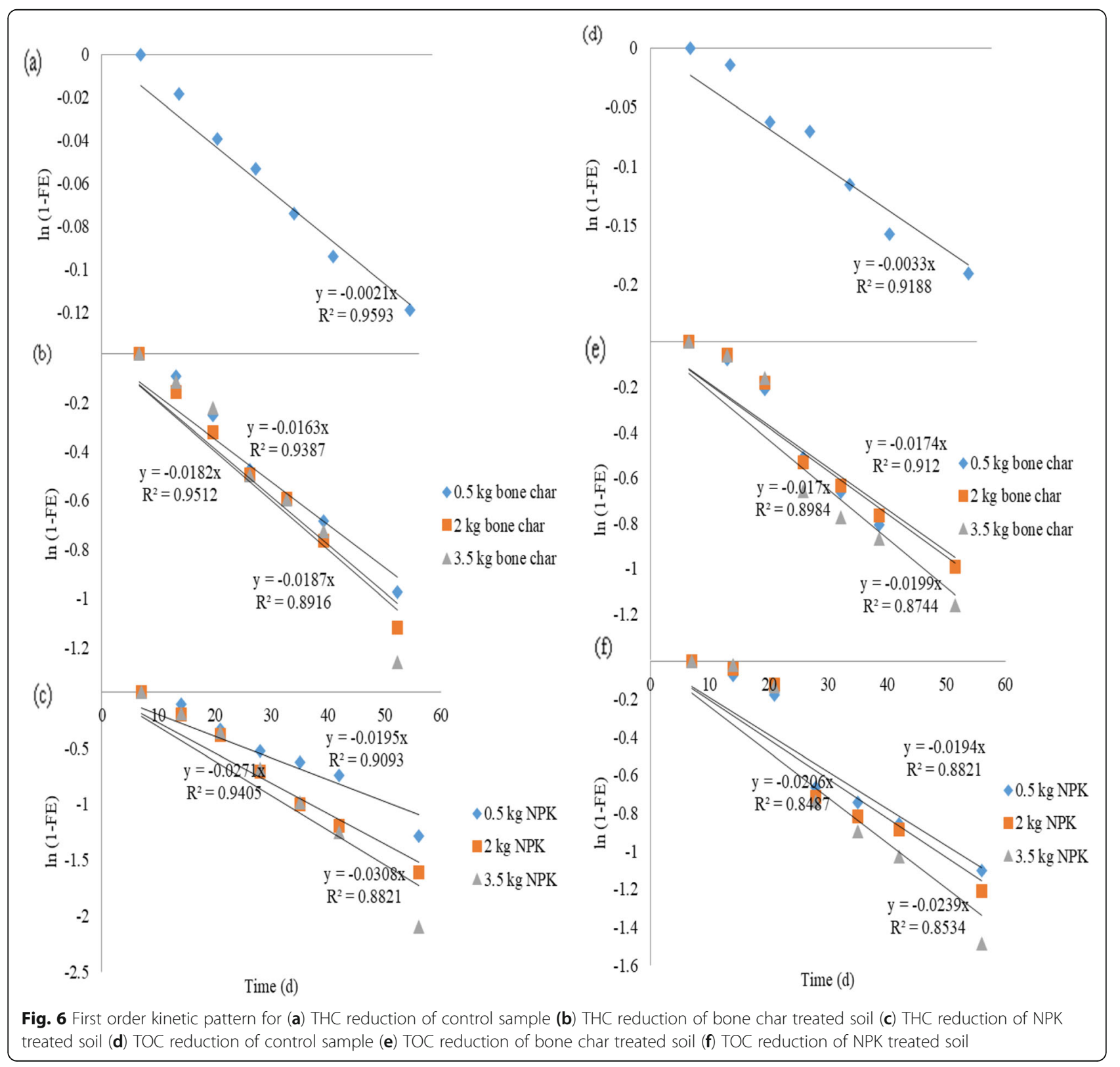


consequently half-life of 23 and $30 \mathrm{~d}$ respectively. This is further proof of the effectiveness of this condition in the bioremediation process. The high values of the $\mathrm{R}^{2}$ statistic across most of the treatment conditions indicate the sufficiency of the model in predicting these processes. It also shows that the models adequately describe the variability of the removal of the THC and TOC contaminants to the extent of their correlation. Physical inspection of the site indicates tremendous effect of the remediation process on the contaminated soil (Fig. 7).

The general trend in the THC degradation profile was observed to follow similar trend reported by Ofoegbu et al. [39]. The kinetics of the remediation process also corroborated the physical evidence of the process (Fig. 7). The kinetic studies of the first order constant obtained in this study, using NPK as biostimulant for the remediation of the soil corroborates the range of $0.007-$
$0.042 \mathrm{~d}^{-1}$ earlier reported [39]. Results from this study also show the significant effect and contribution of bone char as a bio-stimulant in the remediation of the hydrocarbon contaminated site. These effects were comparable to those of the NPK grade which indicate their suitability as a viable alternative. More so, the first order kinetics is comparable to that obtained for the NPK grade. Although the higher performance of the NPK grade fertilizer has been attributed to its nitrogen and phosphorous content, leaching of the soil nutrients and loss of soil texture are some of the side effects associated with its use in addition to the risk of toxicity to aquatic life. With both grades of fertilizer, the bio-stimulation efficiency was above $70 \%$ for both THC and TOC in crude oil contaminated soil, whereas the degradation was above $60 \%$ which is a strong indication of the effectiveness of the process. The $\mathrm{R}^{2}$ value obtained from the
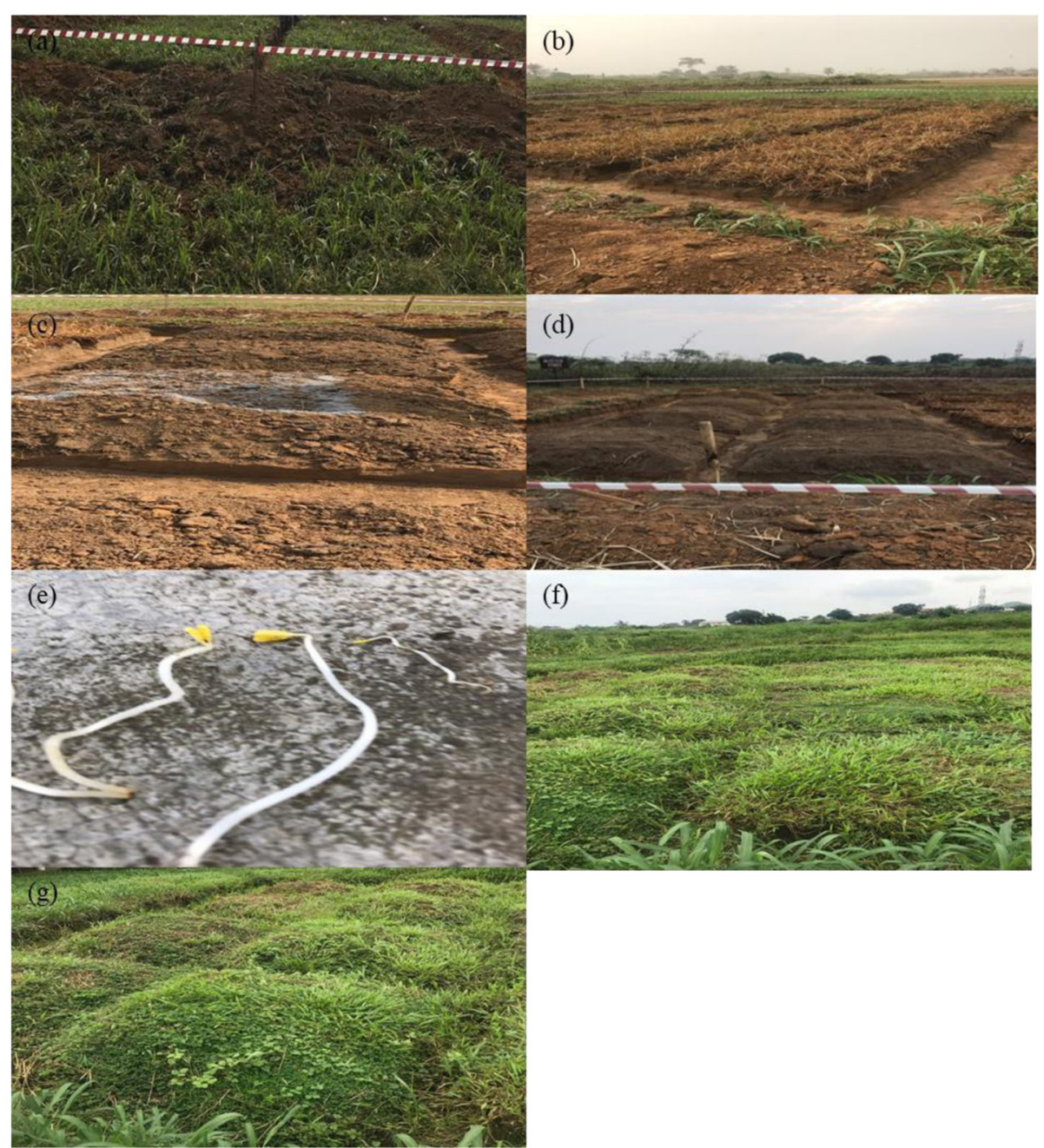

(f)

Fig. 7 Pictorial views of experimental site at various stages of treatment (a) Delineated portion contaminated with crude oil, (b) Crude oil contaminated soil with dead plants 2 weeks after contamination, (c) Remediation treatment with Bone Char/NPK, (d) $14 \mathrm{~d}$ after treatment, (e) 30 $\mathrm{d}$ after treatment with growths, (f) $45 \mathrm{~d}$ after treatment, (g) $60 \mathrm{~d}$ after treatment 
kinetic models indicates the reliability of the models for future predictions and the attenuation of the samples. Based on the indices considered in this study, it can be deduced that enrichment of the bone char fertilizer can make it a credible alternative for NPK (inorganic fertilizer).

\section{Conclusions}

This work has successfully shown the efficacy of the bone char (organic) and NPK (inorganic) fertilizers in the remediation of hydrocarbon contaminated soil. Vital information on the kinetics of the process, degradation, and biostimulation efficiency has been evaluated. Although the inorganic fertilizer improved the contaminated soil, this study has shown that this organic fertilizer can provide a viable alternative. The amount of fertilizer had a direct effect on soil improvement and microbial growth. This gave rise to an appreciable reduction of the THC and TOC. Enrichment of the organic fertilizer will boost its capacity for improving the recovery of oil spilled sites across this region.

\section{Acknowledgements}

The authors are grateful to the management and staff of Chemical Engineering laboratory and Ballantyne research and analysis resources Itd Port Harcourt for their technical support.

\section{Authors' contributions}

O०O provided data curation, draft manuscript preparation, data analysis and modelling. IJO provided the conceptualization, supervision and bench work. All authors read and approved the final manuscript.

\section{Funding}

No funding was received for this study.

\section{Availability of data and materials}

All data generated or analyzed during this study are provided.

\section{Declarations}

\section{Competing interests}

The authors declare they have no competing interests.

Received: 31 May 2021 Accepted: 27 January 2022

Published online: 21 February 2022

\section{References}

1. Yavari S, Malakahmad A, Sapari NB. A review on phytoremediation of crude oil spills. Water Air Soil Poll. 2015;226:279.

2. Alvarez PJJ, IIIman WA. Bioremediation technologies. Bioremediation and natural attenuation: process fundamentals and mathematical models. Hoboken: John Wiley \& Son; 2006. 351-455.

3. Bundy K, Mowat F, Taverna P, Shettlemore M. Measurement of pollutant distribution, toxicity, and effectiveness of emerging soil remediation techniques. Wise DL, Trantolo DJ, Cichon EJ, Inyang HI, Stottmeister U, editors. Remediation engineering of contaminated soils. New York: Marcel Dekker, Inc:; 2000. 113-54.

4. El-Sheekh MM, Mahmoud YAG. Technological approach of bioremediation using microbial tools: bacteria, fungi, and algae. Bhakta JN, editor. Handbook of research on inventive bioremediation techniques. Hershey: IGI Global; 2017. 134-54.

5. Zwetsloot MJ, Lehmann J, Solomon D. Recycling slaughterhouse waste into fertilizer: how do pyrolysis temperature and biomass additions affect phosphorus availability and chemistry? J Sci Food Agr. 2015;95:281-8.
6. Azubuike CC, Chikere CB, Okpokwasili GC. Bioremediation techniquesclassification based on site of application: principles, advantages, limitations and prospects. World J Microb Biot. 2016;32:180.

7. Kalantary RR, Mohseni-Bandpi A, Esrafili A, Nasseri S, Ashmagh FR, Jorfi S, et al. Effectiveness of biostimulation through nutrient content on the bioremediation of phenanthrene contaminated soil. J Environ Health Sci. 2014;12:143.

8. Mishra S, Jyot J, Kuhad RC, Lal B. Evaluation of inoculum addition to stimulate in situ bioremediation of oily-sludge-contaminated soil. Appl Environ Microb. 2001;67:1675-81.

9. Chorom M, Sharifi HS, Motamedi H. Bioremediation of a crude oil-polluted soil by application of fertilizers. Iran J Environ Health. 2010;7:319-26.

10. Eneje RC, Nwagbara C, Uwumarongie-llori EG. Amelioration of chemical properties of crude oil contaminated soil using compost from Calapoigonium mucunoides and poultry manure. Int Res J Agric Sci Soil Sci. 2012;2:246-51

11. Daka ER, Moslen M, Ekeh CA, Ekweozor IKE. Sediment quality status of two creeks in the upper Bonny Estuary, Niger Delta, in relation to urban/ industrial activities. Bull Environ Contam Tox. 2007;78:515-21.

12. Ayotamuno MJ, Kogbara RB, Agunwamba JC. Bioremediation of a petroleum-hydrocarbon polluted agricultural soil at various levels of soil tillage in Port Harcourt, Nigeria. Niger J Technol. 2006;25:44-51.

13. Ikiogha DB, Otaraku IJ, Momoh YL, Welcome MO. Comparative effects of bone char and NPK agricultural fertilizers on hydrocarbon utilizing bacteria and fungi in crude oil polluted soil. Am Sci Res J Eng Tech Sci. 2019;55:35-49.

14. Bray RH, Kurtz LT. Determination of total, organic, and available forms of phosphorus in soils. Soil Sci. 1945;59:39-46.

15. Bouyoucos GJ. Hydrometer Method improved for making particle size analyses of soils. Agron J. 1962;54:464-5.

16. Day PR. Particle fractionation and particle-size analysis. Black CA, Evans DD, Ensminger LE, White JL, Clark FE, Dinauer RC, editors. Methods of soil analysis: part 1 physical and mineralogical properties, including statistics of measurement and sampling. 1st ed. Madison: American Society of Agronomy, Inc.; 1965. 545-67.

17. Barrow Gl, Feltham RKA, editors. Cowan and steel's manual for the identification of medical bacteria. 3rd ed. Cambridge: Cambridge University Press; 1993.

18. Garrity GM, Holt JG, Hatchikian EC, Ollivier B, Garcia JL. Phylum BIII Thermodesulfobacteria phy. nov. Boone DR, Castenholz RW, Garrity GM, editors. Bergey's manual of systematic bacteriology. New York: Springer; 2001. 388-93.

19. Harrigan WF. Determination of the number, and detection, of viable microorganisms in a sample. Laboratory methods in food microbiology. 3rd ed. San Diego: Academic Press; 1998. 52-70.

20. Khan TF, Ahmed MM, Huq SMI. Effects of biochar on the abundance of three agriculturally important soil bacteria. J Agric Chem Environ. 2014; 3:31-9.

21. Umboh SD, Salaki CL, Tulung M, Mandey LC, Maramis RTD. The isolation and identification of fungi from the soil in gardens of cabbage were contaminated with pesticide residues in subdistrict Modoinding. Int J Res Eng Sci. 2016;4:25-32.

22. Odokuma LO, Dickson AA. Bioremediation of a crude oil polluted tropical rain forest soil. Global J Environ Sci. 2003;2:29-40.

23. OpenStax, Parker N, Schneegurt M, Thi Tu AH, Forster BM, Lister P. Microbiology. Houston: OpenStax; 2016.

24. Kalita M, Devi A. Study on the effects of soil $\mathrm{pH}$ and addition of N-P-K fertilizer on degradation of petroleum hydrocarbon present in oil contaminated soil. Int J Chem Petrochem Technol. 2012;2:9-22.

25. Hewelke E, Szatylowicz J, Hewelke P, Gnatowski T, Aghalarov R. The impact of diesel oil pollution on the hydrophobicity and $\mathrm{CO}_{2}$ efflux of forest soils. Water Air Soil Poll. 2018;229:51.

26. Gorbovskiy KG, Norov AM, Kochetova IM, Sokolov W, Mikhaylichenko AI. Study of structural and mechanical properties of mineral fertilizer granules. Theor Found Chem Eng. 2019;53:620-5.

27. Kwon SJ, Kim HR, Roy SK, Kim HJ, Boo HO, Woo SH, et al. Effects of nitrogen, phosphorus and potassium fertilizers on growth characteristics of two species of bellflower (Platycodon grandiflorum). J Crop Sci Biotech. 2019;22:481-7.

28. Okonwu K, Mensah SI. Effects of NPK (15:15:15) fertilizer on some growth indices of pumpkin. Asian J Agric Res. 2012;6:137-43. 
29. Nafiu AK, Togun AO, Abiodun MO, Chude VO. Effects of NPK fertilizer on growth, dry matter production and yield of eggplant in southwestern Nigeria. Agric Biol J N Am. 2011;2:1117-25.

30. Adhikari RC. Effect of NPK on vegetative growth and yield of Desiree and Kufri Sindhuri potato. Nepal Agric Res J. 2009;9:67-75.

31. Chikere CB, Obieze CC, Chikere BO. Biodegradation of artisanally refined diesel and the influence of organic wastes on oil-polluted soil remediation. Sci Afr. 2020;8:e00385.

32. Hesnawi RM, Adbeib MM. Effect of nutrient source on indigenous biodegradation of diesel fuel contaminated soil. APCBEE Procedia. 2013;5: $557-61$

33. Nduka JK, Umeh LN, Okerulu IO, Umedum LN, Okoye HN. Utilization of different microbes in bioremediation of hydrocarbon contaminated soils stimulated with inorganic and organic fertilizers. J Pet Environ Biotechnol. 2012;3:1000116

34. Thavasi R, Jayalakshmi S, Banat IM. Effect of biosurfactant and fertilizer on biodegradation of crude oil by marine isolates of Bacillus megaterium, Corynebacterium kutscheri and Pseudomonas aeruginosa. Bioresour Technol. 2011:102:772-8.

35. Vyas TK, Dave BP. Effect of addition of nitrogen, phosphorus and potassium fertilizers on biodegradation of crude oil by marine bacteria. Indian J Mar Sci. 2010:39:143-50.

36. Rawat J, Saxena J, Sanwal P. Biochar: a sustainable approach for improving plant growth and soil properties. Abrol V, Sharma P, editors. Biochar - an imperative amendment for soil and the environment. IntechOpen: London; 2019.

37. Kumar S, Stecher G, Tamura K. MEGA7: molecular evolutionary genetics analysis version 7.0 for bigger datasets. Mol Biol Evol. 2016;33:1870-4.

38. Chikere CB, Obieze CC, Okerentugba P. Molecular assessment of microbial species involved in the biodegradation of crude oil in saline Niger Delta sediments using bioreactors. J Bioremediation Biodegredation. 2015;6: 1000307.

39. Ofoegbu RU, Momoh YOL, Nwaogazie IL. Bioremediation of crude oil contaminated soil using organic and inorganic fertilizers. J Pet Environ Biotechnol. 2015;6:1000198.

\section{Publisher's Note}

Springer Nature remains neutral with regard to jurisdictional claims in published maps and institutional affiliations.

Ready to submit your research? Choose BMC and benefit from:

- fast, convenient online submission

- thorough peer review by experienced researchers in your field

- rapid publication on acceptance

- support for research data, including large and complex data types

- gold Open Access which fosters wider collaboration and increased citations

- maximum visibility for your research: over $100 \mathrm{M}$ website views per year

At $\mathrm{BMC}$, research is always in progress.

Learn more biomedcentral.com/submissions 